\begin{tabular}{|l|l|l|}
\hline \multicolumn{2}{|c|}{ PublisherInfo } \\
\hline \hline PublisherName & $:$ & BioMed Central \\
\hline \hline PublisherLocation & $:$ & London \\
\hline \hline PublisherImprintName & $:$ & BioMed Central \\
\hline \hline
\end{tabular}

\title{
Tissue-specific circadian cycles
}

\begin{tabular}{|l|l|l||}
\hline \multicolumn{2}{|c||}{ ArticleInfo } \\
\hline \hline ArticleID & $:$ & 4360 \\
\hline \hline ArticleDOI & $:$ & $10.1186 /$ gb-2002-3-8-reports0046 \\
\hline \hline ArticleCitationID & $:$ & reports0046 \\
\hline \hline ArticleSequenceNumber & $:$ & 27 \\
\hline \hline ArticleCategory & $:$ & Paper report \\
\hline ArticleFirstPage & $:$ & 1 \\
\hline \hline ArticleLastPage & $:$ & 4 \\
\hline \hline & & RegistrationDate : 2002-6-3 \\
ArticleHistory & $:$ & Received \\
\hline \hline ArticleCopyright & $:$ & BioMed Central Ltd2002 \\
\hline \hline ArticleGrants & $:$ & \\
\hline \hline
\end{tabular}




\begin{tabular}{|l|l|l|}
\hline ArticleContext & $:$ & 130593388 \\
\hline
\end{tabular}

\section{Jeffrey T Ehmsen}

\section{Summary}

Examination of cyclic gene expression in the suprachiasmatic nuclei (SCN) and liver suggests tissue-specific circadian cycles corresponding to organ-specific physiological functions

\section{Significance and context}

The hypothalamic suprachiasmatic nucleus ( $\mathrm{SCN})$ serves as a master pacemaker in the regulation of roughly 24-hour cycles of physiology and behavior - so-called circadian rhythms. The liver is also an important physiological mediator, because of its pivotal role in metabolism and energy production. Panda et al. have carried out a global analysis of circadian transcription patterns in the SCN and liver in an attempt to uncover genes regulated in a circadian fashion and to profile the transcriptional rhythms associated with tissue-specific physiological activities.

\section{Key results}

Temporal patterns of gene expression in the suprachiasmatic nuclei and liver of C57BL/6J mice previously entrained to a standard dark-light cycle were examined by microarray analysis. Transcripts showing a cosine-like periodic variation of 20-28 hours were considered to be regulated in circadian fashion. Approximately 650 cycling transcripts were revealed, including at least eight previously identified as expressed with circadian periodicity. Only 28 of these genes overlapped between the SCN and liver, perhaps representing components of the circadian oscillator itself. Intriguingly, the remaining nonoverlapping cycling transcripts are generally expressed at much lower levels in the other tissue, suggesting tissue-specific circadian regulation of transcription relevant to the function of the particular organ. Examination of the functions of these transcripts suggests that circadian control of many pathways is probably exerted at biochemically rate-limiting steps. In the SCN, for example, circadian control of genes involved in the synthesis, processing and release of neurotransmitters or in regulating the levels of channel proteins and receptors could influence neuronal signaling. Tightly regulated synthesis and degradation of periodically expressed proteins is critical. Indeed, a majority of the cycling transcripts in the SCN are implicated in protein synthesis, including ribosomal components, proteins involved in folding and members of the ubiquitin-mediated protein-degradation pathway. In the liver, cycling levels of membrane channels, transporters and enzymes involved in nutrient metabolism could regulate the use and movement of metabolites. Peak expression of such transcripts is also correlated with 
the expected temporal activity of the relevant tissue, with peak expression of regulated genes in the SCN occurring at 10 and 22 hours in the circadian cycle, roughly anticipating dusk and dawn.

\title{
Links
}

A publicly accessible Database $\% 20$ of $\% 20$ circadian $\% 20$ gene $\% 20$ expression is provided by the authors, containing the full results of the genes examined in this study and links to other public sources of information on circadian regulation.

\section{Conclusions}

If the SCN and liver can be considered representative, then circadian regulation of genes seems to be tissue-specific and relevant to the primary functions of the organ. Many cycling genes show appropriately timed expression profiles and have rate-limiting roles in their respective physiological pathways.

\section{Reporter's comments}

Analysis of transcripts regulated with circadian periodicity in other tissues is now certain to follow, and may assist in understanding the causes or symptoms of sleep disorders and certain psychopathologies. An ambitious but intriguing undertaking will be to define signaling cascades or other factors that link the cyclic activities of the SCN, as a master regulator, with the orchestrated events occurring with a circadian periodicity in the various organs.

\section{Table of links}

\author{
Cell
}

Database $\% 20$ of $\% 20$ circadian $\% 20$ gene $\% 20$ expression 


\section{References}

1. Panda S, Antoch MP, Miller BH, Su AI, Schook AB, Straume M, Shultz PG, Kay SA, Takahashi JS, Hogenesch JB: Coordinated transcription of key pathways in the mouse by the circadian clock. Cell. 2002, 109: 307-320. 